\title{
ПРОБЛЕМЫ И ПЕРСПЕКТИВЫ ИССЛЕДОВАНИЯ СОВРЕМЕННЫХ КОНЦЕПЦИЙ, МОДЕЛЕЙ И ТЕХНОЛОГИЙ УПРАВЛЕНИЯ МЕЖДУНАРОДНЫМИ КОНФЛИКТАМИ
}

Аннотация: в статье представлены результаты анализа основных проблем и перспектив исследования современных концепций, моделей и технологий управления современными международными конфликтами. Дана классификация научных подходов к исследованию роли технологий прямого и опосредованного информационно-психологического воздействия в управлении международными конфликтами как в интересах их полного либо частичного урегулирования, так и в интересах политической эскалаичи.

Ключевые слова: политология, национальная безопасность, управление международными конфликтами, международные отношения, внешняя политика, политические конфликты, психологические технологии, психологические операции, информационная война, информационная политика.

Review: the article presents the results of the analysis of the key problems and perspectives in the studies of the modern concepts, models, and technologies for the international conflict management. The author provides a classification of scientific approaches towards the studies of the role of technologies for the direct and indirect information and psychological influence in the sphere of international conflict management both in the interests of their complete or partial regulation, and in the interests of their political escalation.

Keywords: political science, national security, international conflict management, international relations, foreign policy, political conflicts, psychological technologies, psychological operations, information war, information policy.

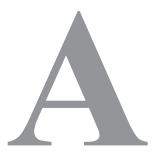

нализ закономерностей развития современного человечества говорит глобального информационного общества, общества цивилизационных перемен, предвещающего кардинальные изменения во всех сферах личной и общественной жизни. В Доктрине информационной безопасности Российской Федерации говорится о том, что настоящий «этап развития общества характеризуется возрастающей ролью информаци- онной сферы» ${ }^{1}$ Информационная сфера, как системообразующий фактор жизни общества, активно влияет на состояние политической, экономической, оборонной и других составляющих безопасности Российской Федерации.

Национальная безопасность Российской Федерации существенным образом зави-

\footnotetext{
${ }^{1}$ Доктрина информационной безопасности Российской Федерации.- М., 200.—C.1.
} 
сит от обеспечения информационной безопасности, и в ходе технического прогресса эта зависимость, по нашему мнению, будет возрастать. Так, Доктрина информационной безопасности Российской Федерации ${ }^{1}$ относит к внешним источникам угроз безопасности России разработку рядом государств концепций информационных войн; разработанные Советом Безопасности России «Основы государственной политики в области обеспечения информационно-психологической безопасности» ${ }^{2}$ определяют государственную информационную политику в условиях информационной войны как центральный компонент системы обеспечения безопасности и, одновременно, указывают на неэффективность использования общих принципов, средств и методов существующей сегодня информационной политики в условиях острых информационно-психологических конфликтов; материалы парламентских слушаний «Угрозы и вызовы в сфере информационной безопасности» ${ }^{3}$ указывают не только на неэффективность действующей государственной политики в условиях психологических войн, но и предполагают, что возможной причиной такой неэффективности может являться принципиальная неприменимость общих форм и методов политического урегулирования конфликтов, в том числе - международных, в специальных,

\footnotetext{
${ }^{1}$ Доктрина информационной безопасности Российской Федерации // Российская газета. 2000. 28 сент.

${ }^{2}$ Основы государственной политики в области обеспечения информационно-психологической безопасности. Проект. Разработан по заказу Совета Безопасности Российской Федерации. М.: Институт психологии РАН, 2000.

3 “Угрозы и вызовы в сфере информационной безопасности", Материалы парламентских слушаний в Государственной Думе ФС РФ, ГД СФ России, 1996 г.
}

или особых, условиях, которые создает информационно-психологическая война.

Политическое урегулирование конфликтов, т.е. нахождение взаимоприемлемого согласия между участниками конфликта политическим путем, при помощи переговоров, политических технологий и процедур ${ }^{4}$, сегодня является важнейшей категорией современной конфликтологии и политической науки вообще. Как указывает М.М. Лебедева, «технологии мирного урегулирования конфликтов приобретают особое значение в современных условиях, становясь главным фактором сохранения и развития человеческой цивилизации» ${ }^{5}$. Поиск и разработка таких технологий строится на выявлении общих закономерностей в конфликтах, позволяющие разрешать их мирными средствами. Сравнительный анализ таких закономерностей позволяет дать прогноз возникновения и развития конфликта, определить эффективные методы его урегулирования, предотвращающие насильственный формы дальнейшего развития. Поиск общих закономерностей и технологий урегулирования современных конфликтов это качественно новый уровень владения инструментами политического регулирования современных международных отношений. В условиях информационного общества вершиной развития такого инструментария становятся информационно-психологические технологии, значение которых в урегулировании современных конфликтов со временем будет только возрастать ${ }^{6}$.

\footnotetext{
${ }^{4}$ Лебедева М.М. Политическое урегулирование конфликтов: подходы, решения, технологии.- М.: Аспект Пресс., 1999.- 271 с.

5 Там же.

${ }^{6}$ Манойло А. В. Проблемы и перспективы исследования информационно-психологических технологий разрешения международных конфликтов. // Право и политика.-2008.- № 3.
} 
Однако, к сожалению, сегодня российское обществоведение переживает методологический кризис. Видный ученый-международник, член-корр. РАН А. В. Торкунов справедливо указывает на слабое производство в России теоретических обобщений, на необходимость обновления методологии общественно-научных исследований, создания «новой методологической парадигмы» ${ }^{1}$. В этой новой парадигме достойное место должна занять социальная психология и «управление процессами восприятия человеком жизненной реальности, управление рефлексией $)^{2}$. Именно поэтому при постановке проблемы исследования роли и места информационно-психологического фактора в современных конфликтах необходимо учитывать, что она находится на стыке ряда дисциплин, каждая из которых имеет свою методологию, степень и глубину разработанности.

С одной стороны, это - политологические и социологические исследования практики применения современных технологий информационно-психологического воздействия на массовое и индивидуальное сознание в международных отношениях, степени их влияния на современные политические процессы (разновидностью которых являются политические конфликты) и принципиальной возможности рассматривать эти технологии как эффективный инструмент достижения поставленных целей. При этом, принципиальным моментом является именно технологический аспект управляющего информационно-психологического

\footnotetext{
${ }^{1}$ «парадигмы», понимаемой как теории исследования, признанного научным сообществом достижением в сфере получения знаний, дающим модель постановки проблемы и методов ее решения. См. Т. Kuhn, The Structure of Scientific Revolution. Chicago, 1970.

${ }^{2}$ Независимая газета, 7 декабря 2007 г.
}

воздействия, т.е. возможность разработки и апробации таких способов воздействия, которые в качестве инструментов управления конфликтами обладали бы технологической универсальностью - способностью многократного тиражирования, применимостью к различным видам современных конфликтов без привязки к их сугубо внутренним индивидуальным особенностям.

С другой стороны, важнейшим вопросом исследования является изучение принципиальной управляемости современных политических конфликтов с помощью психологического воздействия. Известно, что в арсенале психологических операций существует значительный набор способов и инструментов психологического воздействия на политические процессы, от методов политической рекламы и пропаганды до технологий информационной войны. И все они так или иначе оказывают воздействие на политику. Однако, вопрос о том, способны ли современные информационно-психологические технологии управлять политическими конфликтами самостоятельно, без обязательного привлечения других управляющих механизмов, и, если - да, то, на каких именно стадиях развития современного конфликта, по-прежнему остается открытым ${ }^{3}$.

При рассмотрении современных политических конфликтов в качестве объектов информационно-психологического управления, встает законный вопрос о том, может ли это управление привести к разрешению конфликтной ситуации.

Сегодня известно множество примеров использования современных технологий психологического воздействия в операциях ин-

\footnotetext{
${ }^{3}$ Манойло А.В. Проблемы и перспективы исследования информационно-психологических технологий разрешения международных конфликтов. // Право и политика.-2008.— № 3 .
} 
формационной войны с целью развязывания и эскалации международных конфликтов, в том числе - переходящих, в результате применения агрессивных информационнопсихологических технологий, в стадию прямого вооруженного столкновения. Примером такого использования психологического воздействия на конфликты являются военные операции конца XX- начала XXI вв. в Ираке, Афганистане, Гаити, Сомали, на Балканах. По мнению видного ученого-международника А. В. Манойло, это, несомненно, пример управляющего воздействия, причем воздействия очень эффективного, не имеющего аналогов на протяжении всего предшествующего периода истории международных отношений. Тем не менее, эти примеры не могут дать ответ, можно ли использовать аналогичные по своей природе технологии не только для эскалации, но и для политического урегулирования международных конфликтов ${ }^{1}$.

Кроме того, важным является вопрос о роли механизма политического урегулирования среди других существующих механизмов управления конфликтами.

И, наконец, необходимо учитывать, что в результате формирования информационного общества и стремительного развития новых политических технологий, основанных на парадигме информационного превосходства, в современных, в том числе - международных, конфликтах возникла и оформилась новая стадия, которая получила название информационно-психологической войны ${ }^{2}$.

\footnotetext{
${ }^{1}$ Манойло А. В. Проблемы и перспективы исследования информационно-психологических технологий разрешения международных конфликтов. // Право и политика.-2008.- № 3.

${ }^{2}$ Манойло А. В. Технологии несилового разрешения современных конфликтов. / А. В. Манойло; под ред. проф. А. И. Петренко.- М.: Горячая линия - Телеком, 2008. — 392 с.: ил.
}

Считается, что политический конфликт переходит в фазу информационно-психологической войны в том случае, если одна или несколько сторон, вовлеченных в конфликт, останавливаются на выборе силового решения, но при этом, в целях достижения максимального конкурентного преимущества, выбирают для достижения политических целей такие формы и методы агрессии, которые, наряду с внезапностью, обеспечили бы нападающему значительный период скрытости. Сегодня таким способом политического насилия является только арсенал средств, методов и технологий информационно-психологической войны. В этом смысле тайные операции психологической войны в современном конфликте предшествуют непосредственно военной фазе, хотя, конечно, могут различным образом сочетаться с актами прямой вооруженной агрессии, которые в информационно-психологической войне необходимы для инициирования цепных психологических реакций в массовом сознании населения и играют известную роль «спускового крючка»

На критической стадии перехода от политических методов к методам прямого вооруженного противостояния возникает встречное воздействие на политический конфликт двух видов внешнего управления, диаметрально отличающихся по преследуемым целям: технологий иноформационно-психологической войны, направленных на нулевое разрешение политического конфликта через его эскалацию и нанесение одной из сторон, вовлеченных в конфликт, неприемлемого ущерба, и технологий урегулирования, направленных на то, чтобы

\footnotetext{
${ }^{3}$ Манойло А.В. Технологии несилового разрешения современных конфликтов. / А.В. Манойло; под ред. проф. А.И. Петренко.- М.: Горячая линия - Телеком, 2008.— 392 с.: ил.
} 
найти компромиссное решение с большими для себя преимуществами. Как справедливо отмечает А. В. Манойло, вопрос о применимости технологий политического урегулирования конфликтов, находящихся в фазе информационно-психологической войны, таким образом, сводится в первую очередь к возможности рассматривать современную информационно-психологическую войну в качестве объекта политического управления ${ }^{1}$.

Существующие концепции регулирования такой сложной формы социально-политических отношений как психологическая война сегодня, в основном, сводятся к принципу противодействия, и в этом смысле информационно-психологические технологии противодействия операциям ИПВ также относятся к технологиям урегулирования современных конфликтов. Однако у концепции противодействия есть ряд неустранимых, с нашей точки зрения, недостатков: противодействие начинается тогда, когда операции психологической войны выходят из скрытой (латентной) стадии, т. е.- выявлены и распознаны жертвой нападения, что происходит практически во всех случаях слишком поздно для того, чтобы предотвратить наносимый ущерб и воспрепятствовать перетеканию конфликта в стадию прямого вооруженного столкновения.

Вопрос об управлении психологической войной вообще и в международных конфликтах, в частности, в современной научной литературе практически не поднимается; возможно, исключение составляют отдельные работы ${ }^{2}$, где впервые психологи-

\footnotetext{
${ }^{1}$ Манойло А.В. Психологические операции США в Ираке. / А. В. Манойло // Космополис._2008.—№ 1.C.124-128.

${ }^{2}$ И.Н. Панарин. Технологии информационной войны. М.:2003, КСП+, 320 с.; И. Н. Панарин, Информационная
}

ческая война рассматривается на различных уровнях познания: как социальное явление, как поле политических конфликтов, как одна из фаз политического конфликта и как инструмент внешней политики. Изучение теории и практики информационно-психологического воздействия на процессы разрешения современных конфликтов крайне актуально, т.к. эти методы воздействия прочно вошли в арсенал инструментов современной дипломатии. Если такая практика существует, то исследование механизмов информационно-психологического управления конфликтами должно снабдить дипломатию действенными научно-обоснованными технологиями регулирования международных конфликтов ${ }^{3}$.

Отдельно встает немаловажный вопрос о пределах эффективности и границах применимости информационно-психологических технологий разрешения современных конфликтов, из уяснения которого непосредственно вытекает место этих технологий в общем процессе стабилизации системы международных отношений. Любой конфликт в своем развитии проходит через ряд последовательных стадий, каждой из которых характерен свой набор инструментов политического воздействия. Несомненно,

война, PR и мировая политика. М.: 2006, Горячая линия-Телеком, 352 с.; Манойло А.В. Психологические операции США в Ираке. / А. В. Манойло // Космополис.—2008.—№ 1.—C.124-128.; Manoïlo A. V., Gestion de la guerre psychologique dans le cadre de la politique informationnelle de l'Etat.- M.: Politique et société, № 2’2004; Manoilo A. V., Methods of Psychological Warfare Research. - V.: Proceedings of The Forth International Scientific and Methodic Conference "IES2004”, 2004, pp. 372-374.; Manoilo A.V., Psychological Warfare Management. - V.: Proceedings of The Forth International Scientific and Methodic Conference "IES2004", 2004, pp. 375-378.

${ }^{3}$ И. Н. Панарин, Информационная война, PR и мировая политика. М.: 2006, Горячая линия-Телеком, 352 с. 
современные информационно-психологические технологии относятся к одному из таких наборов и не могут быть одинаково эффективны на всех стадиях эволюции политического конфликта. Выявление таких стадий (одной или нескольких) становится одной из актуальных исследовательских задач ${ }^{1}$.

Актуальность исследования роли и места информационно-психологических технологий в управлении современными, в том числе - международными, конфликтами обусловлена следующими объективными факторами.

Во-первых, несмотря на завершение эпохи глобального противостояния, в современном мире количество политических конфликтов не только не сокращается, а продолжает нарастать, причем возникают их новые формы, мало подверженные стабилизирующему воздействию традиционных инструментов политического регулирования. Как указывает М. М. Лебедева, «современные конфликты стали одним из ведущих факторов нестабильности в мире. Будучи плохо управляемыми, они имеют тенденцию к возрастанию, подключению все большего числа участников, что создает угрозу не только тем, кто непосредственно вовлечен в конфликт, но и всем живущим на земле» ${ }^{2}$. Международные отношения все больше становятся полем политических конфликтов.

На передний план выходят региональные конфликты, характеризующиеся высокой интенсивностью, широким применением методов прямой вооруженной агрессии и способностью вовлекать в свою сферу

\footnotetext{
${ }^{1}$ Манойло А.В. Пределы регулирующего воздействия информационно-психологических технологий на международные конфликты / А. В. Манойло // Право и политика.—2008.— № 7.— С.1653-1664.

2 Лебедева М. М. Политическое урегулирование конфликтов: подходы, решения, технологии.- М.: Аспект Пресс., 1999.—271 с.
}

соседние регионы, разрушая исторически сложившиеся там системы коллективной безопасности. Деятельность США по «силовому умиротворению» и «принуждению к демократии» в различных регионах мира не только не устраняет первопричины протекающих там политических конфликтов, но во многих случаях приводит к их эскалации и переходу на новый, более масштабный, уровень. Часто политические конфликты специально инициируются в регионах, имеющих стратегическое экономическое или военное значение, для того, чтобы под видом миротворцев обеспечить там свое военное и политическое присутствие.

Так, политический конфликт в Ираке, ставший новым импульсом для обострения этнических и религиозных противоречий между иракскими суннитами (которых поддерживает Сирия) и шиитами (пользующимися поддержкой Ирана), арабами и курдами, способен вовлечь в затяжной вооруженный конфликт фактически весь Ближний Восток ${ }^{3}$; политический конфликт в Косово не только привел к возникновению в самом центре Европы крупнейшего моноэтнического анклава с населением, принадлежащим к иной культурной традиции, но и стал для международных экстремистов плацдармом для развертывания дальнейшей внешней экспансии (напр., вторжение УЧК в Македонию).

Во-вторых, наряду с обострением традиционных форм и методов политического соперничества, в международных отношениях все большее значение играет этнополитический фактор: как указывает А. В. Манойло, «в современных международных конфликтах, все чаще носящих характер столкновения цивилизаций, центральной проблемой становится сохранение ценностей и национальной

\footnotetext{
${ }^{3}$ Клименко 3.В. Кризис и распад Югославской Федерации //Дисс... канд.полит.наук.— М., 1999.
} 
идентичности, разрушение и трансформация которых сегодня - основная цель политической агрессии. Сам политический конфликт при этом во многом утрачивает черты «конфликта интересов» и становится, в первую очередь, психологическим «конфликтом ценностей», природа которого и способы политического разрешения сегодня практически не познаны» 1 .

Примером такого конфликта может служить Косово, где сегодня происходит столкновение системы ценностей православной христианской цивилизации, радикальных направлений этнического ислама и агрессивной миссионерской социально-культурной традиции американского протестантизма. Другим ярким примером является зарождающийся в самом центре Европы Франции - этнополитический конфликт между коренным населением страны и общинами иммигрантов из мусульманских стран Северной Африки, которые принадлежат к иной культурно-цивилизационной традиции и не разделяют многих европейских ценностей, принципиально отрицают политику культурной интеграции и, по мере накопления собственных ресурсов, начинают заявлять о себе как о новой политической силе. Близкая ситуация складывается с этническими общинами и в Великобритании, вынужденной кардинально пересматривать открытость своих границ.

Угроза нарастания этнополитических конфликтов продолжает сохраняться: сегодня в мире существует более 180-ти государств и лишь не более 20-ти из них этнически однородны; в более $40 \%$ государств мира проживает пять и более национальных меньшинств. На протяжении второй полови-

\footnotetext{
${ }^{1}$ Манойло А.В. Мирное разрешение конфликтов: национальные концепции, модели, технологии / А. В. Манойло // Власть.— 2008.— № 8.- С.79-84.
}

ны XX века в мире было отмечено более 300 этнических конфликтов, которые периодически переходили в стадию насилия. По оценкам ООН, этнические конфликты унесли больше жизней, чем «традиционные» войны.

По мнению А.В. Манойло, разрешение этнополитических «конфликтов ценностей» не может быть найдено исключительно в политической плоскости: во многих районах совместного проживания межэтнические противоречия формировались, накапливались и сохранялись в сознании населения веками и настолько глубоко проникли в историческую память, что их политическая активация у людей нередко проявляется в форме неосознанных, ментально-архетипных, интуитивно- подсознательных действий, не подверженных воздействию разума и логики - категорий, которыми оперирует сознание. В этих условиях обычные методы политического воздействия на конфликтную ситуацию малоэффективны: этническое подсознание не поддается политическому регулированию. Все это требует поиска новых инструментов, способных оказывать стабилизирующее воздействие на сознание и подсознание населения в зонах конфликтов,- - новых, информационно-психологических, технологий управления политическими процессами, конфликтами и кризисами ${ }^{2}$.

B-третьих, международная деятельность по урегулированию политических конфликтов сегодня переживает системный кризис, требующий не только поиска новых подходов и способов воздействия на конфликтные ситуации, но и формирования новых парадигм управления политическими конфликтами.

В настоящее время в мире существует три основных механизма, призванных под-

\footnotetext{
${ }^{2}$ Манойло А.В. Мирное разрешение конфликтов: национальные концепции, модели, технологии / А. В. Манойло // Власть.— 2008.- № 8.- С.79-84.
} 
держивать стабильность в международных отношениях и урегулировать возникающие политические конфликты:

- международные институты и системы коллективной безопасности $(\mathrm{OOH}$, ОБСЕ);

- «оборонительные» военно-политические союзы, оставшиеся в наследство от «холодной войны» и перепрофилированные на «миротворческую деятельность» (HATO, 3ЕC);

- государства-волонтеры, готовые собственными силами добровольно вести миротворческую деятельность по всему миру, выступая в роли всемирного арбитра и используя для этого свой международный авторитет и мощный военно-политический потенциал (США). Все они сегодня переживают глубокий кризис, вызванный собственной неэффективностью и ограниченной способностью влиять на политические конфликты в современных условиях.

Так, миротворческая деятельность США и НАТО в Югославии не только не привела к урегулированию конфликта, но и превратила этот регион в крупнейший очаг политической напряженности в Европе, имеющий опасные тенденции к расширению и вовлечению в конфликт иных участников; миротворческая операция США в Ираке погрузила страну в военный и политический хаос; операция в Афганистане, так и не устранив с политической сцены Талибан, обострила противоречия между исламским миром и европейскими государствами, вовлеченными, при непосредственном участии США, в затяжной афганский конфликт.

Непрекращающиеся попытки США принизить роль и, фактически, отстранить ООН от руководства миротворческой деятельностью, существенно снижают возмож- ности ООН по урегулированию современных конфликтов ${ }^{1}$.

Системно-функциональный кризис миротворческой деятельности, осуществляемой США и НАТО, наглядно демонстрирует неэффективность существующих сегодня базовых парадигм урегулирования конфликтов: «силового умиротворения», «гуманитарных интервенций», «экспорта демократии» и «борьбы с международным терроризмом», и требует разработки новых теоретических концепций, адекватных современным угрозам и вызовам в сфере регулирования международных конфликтных отношений. В научном плане это должно найти выражение и в разработке новой методологии, основанной на междисциплинарном подходе к исследованию разрешения современных конфликтов.

В четвертых, в условиях формирования информационного общества многократно повышается значимость информационнопсихологического фактора в управлении современными конфликтами. «Мировые процессы - это не только то, что происходит на самом деле,»- отмечает А. В. Торкунов,«но и то, что люди думают о том, что происходит» ${ }^{2}$.

Сегодня в результате стремительного развития новых политических технологий, основанных на парадигме информационного превосходства, в современных политических конфликтах возникла и оформилась новая стадия,- - информационно-психологическая война, занимающая промежуточную ступень между

\footnotetext{
${ }^{1}$ «... при силовом и экономическом доминировании США... при решении принципиальных вопросов международной безопасности ставка делается на западные институты ..., на ослабление роли Совета Безопасности $\mathrm{OOH»} \mathrm{-} \mathrm{Концепция} \mathrm{внешней} \mathrm{политики} \mathrm{Российской}$ Федерации от 17.12.1997 г., в редакции Указа Президента РФ от 10.01.2000 г. № 24.

${ }^{2}$ Независимая газета, 7 декабря 2007 г.
} 
стадией переговоров и вооруженным столкновением и являющаяся в конфликте «поворотной точкой» - от мирной фазы к военной.

Вместе с тем, возникновение в современных конфликтах новой фазы - информационно-психологической войны - создает новые возможности для управления конфликтами, в т.ч.- в целях их разрешения или урегулирования. Так как сегодня в системе международного права нет механизмов, ограничивающих применение технологий психологические войны, поиск новых эффективных способов, методов и технологий стабилизирующего воздействия на конфликт, находящийся в фазе ИПВ, выдвигается на передний план современной миротворческой деятельности.

В пятых, в условиях формирования информационного общества необходима выверенная государственная информационная политика ${ }^{1}$. Значение ее возрастает в условиях информационной борьбы, и, особенно, в условиях психологических войн ${ }^{2}$. При том встает практический вопрос - о научно-аналитическом обеспечении реализации концепции информационной безопасности России, которая понимается как состояние защищенности ее национальных интересов в информационной сфере, определяющихся совокупностью сбалансированных интересов личности, общества и государства. ${ }^{3}$ Не случайно в Концепции внешней политики обеспечение информационной безопасности указано в качестве одного

\footnotetext{
${ }^{1}$ Мелюхин И.С. Информационное общество: истоки, проблемы, тенденции развития. М. 1999, с.7

2 Попов В. Д. Информациология и информационная политика. М.: Изд-во РАГС, 2001, 118 с.; он же, Государственная информационная политика: состояние и проблемы формирования, 2002 г.- М.: Массовые информационные процессы в современной России. Очерки/ Отв.ред. А. В. Шевченко. Изд-во РАГС, с. 20

${ }^{3}$ Доктрина информационной безопасности Российской Федерации. Российская газета, 28 сент. 2000 г.
}

из приоритетов Российской Федерации в решении глобальных проблем: «Россия ... уделяет особое внимание такому аспекту укрепления стратегической стабильности как обеспечение информационной безопасности» ${ }^{4}$.

По свидетельствам ряда ученых, в настоящее время разворачивается «третья мировая информационно-психологическая война». Некоторые ученые считают, что холодную войну СССР проиграл по причине поражения в войне информационно-психологической ${ }^{5}$. Признав этот факт, необходимо сформулировать государственную информационную политику, которая позволяла бы решать проблемы адекватного отражения информационно-психологической агрессии.

Также следует учитывать, что в России уже произошли фундаментальные изменения системы социально-политических отношений. Россия стала информационно открытой страной, как для других государств, так и внутри самой себя 6 . В условиях демократизации общества открываются его информационные границы. При этом, главные цели нанесения информационно-психологических ударов - массовое сознание, социальная психика, мораль и нравственность,- становятся все более доступны для негативного внешнего информационного воздействия.

В современных условиях жизненно важно для России сформировать такую политику

\footnotetext{
${ }^{4}$ Концепция внешней политики Российской Федерации от 17.12.1997 г., в редакции Указа Президента РФ от 10.01.2000 г. № 24 .

${ }^{5}$ См.: Лисичкин В.А., Шелепин Л.А. Третья мировая информационно-психологическая война.- М., 1999.; Расторгуев С.П. Информационная война.- М.: Изд-во “Радио и связь”, 1999.; Почепцев Г. Г. Психологические войны.- Изд-ва: “Рефл-бук”, “Ваклер”, 2000.; Прокофьев В.Ф. Тайное оружие информационной войны.- “Синтег”, 1999 и др.

${ }^{6}$ Попов В. Д. Информациология и информационная политика.—- М., 2001,- С.5.
} 
(а, следовательно, и модель развития), которая позволила бы стране устойчиво двигаться вперед наравне с другими странами. Это тем более важно, что политическая сфера формирующегося глобального информационного общества все более превращается в конфликтную сферу информационного противоборства. Происходит нарастание информационно-психологических конфликтов, возрастает их интенсивность и социальная опасность.

Проблема формирования выверенной политики государства в условиях информационно-психологической войны возрастает еще и из-за низкой степени готовности современного российского общества оказывать активное сопротивление любым попыткам манипулирования общественным сознанием, поскольку в массовом сознании граждан еще только формируется понимание той угрозы, которую могут нести современные информационно-психологические войны.

В шестых, признав роль информационно-психологического фактора в управлении современными политическими процессами, у России, находящейся на пересечении интересов североамериканской, восточноазиатской и западноевропейской политики, в формировании собственного политического мировоззрения на формы и способы разрешения современных конфликтов есть две возможности: либо - следовать одной из уже существующих моделей (англо-саксонской, романо-германской или восточноазиатской), либо - искать собственный путь, сочетая в национальной политике сильные стороны всех трех основных подходов и, по возможности, избегая их недостатков ${ }^{1}$.

${ }^{1}$ Манойло А.В. Несиловое регулирование международных конфликтов. Культурно-цивилизационные парадигмы. / А. В. Манойло // Космополис.—2008.—№ 2.
При выборе собственной модели психологического воздействия на современные политические конфликты России необходимо исходить из трех основных принципов:

- получить возможность оказывать прямое психологическое воздействие не только на группы политической элиты, представляющие конфликтующие стороны за столом переговоров или поддерживающих политический контакт с одним из международных посредников, но, в первую очередь, на массовое сознание населения в зонах конфликтов, в том числе - на этнические группы и анклавы, подверженные воздействию экстремистской идеологии;

- избежать вовлечения в конфликт в качестве одной из конфликтующих сторон;

- $\quad$ избежать вступления в прямое конфликтное соприкосновение с ведущими игроками на мировой арене, вовлеченных в этот конфликт в одном из качеств: посредника, миротворца, либо - в качестве одной из сторон, стремящихся урегулировать конфликт на собственных условиях методом прямого силового давления.

Сегодня в научной литературе существует пять основных подходов к исследованию роли и места психологического фактора в разрешении конфликтов. Условно их можно означить как медиа-коммуникативный, информационно-конфликтологический, системно-функциональный, информационнополитический и этноконфликтологический ${ }^{2}$.

Сторонники медиа-коммуникативного подхода считают, что современные технологии информационно-психологического воздействия на массовое и индивидуаль-

\footnotetext{
${ }^{2}$ Манойло А. В. Технологии несилового разрешения современных конфликтов. / А.В. Манойло; под ред. проф. А.И. Петренко.- М.: Горячая линия - Телеком, 2008.— 392 с.: ил.
} 
ное сознание оказывают заметное влияние на внешнюю политику и международные отношения, политические процессы, конфликты и кризисы, но, при этом, сводят указанные технологии практически исключительно к современным технологиям медиа-воздействия, осуществляемого через средства массовой информации и массовой коммуникации.

Авторы, исследующие современные конфликты с позиций международной и политической конфликтологии (информационно-конфликтологический подход), указывают, что в связи с формированием глобального информационного общества в современных конфликтах появилась новый вид конфликтных отношений - информационно-психологическая война. Доминируя в современных международных отношениях, информационно-психологическая война в перспективе станет основной формой современных конфликтов, вытеснив или понизив роль других видов ${ }^{1}$. Поэтому поиск способов и механизмов политического урегулирования конфликтов, находящихся в фазе ИПВ, необходимо также искать в виде технологий информационно-психологического воздействия.

Сторонники системно-функционального подхода видят основной способ регулирования современных конфликтов в разработке технологий управления системной безопасностью и ее политической составляющей, рассматривая комплексную безопасность личности, общества и государства как объект внешнего управления. По сути, в рамках указанного подхода формируется управление конфликтом через механизм обратной свя-

${ }^{1}$ А. Шубин. Россия и мир в 2020 году. Доклад Национального разведывательного совета США «Контуры мирового будущего» М.: Издательство «Европа», 2005.— 224 c. зи, связывающий состояния (в различные моменты времени) поля политических конфликтов и состояния объекта конфликтного воздействия - политической системы, через показатель политической стабильности самой системы - безопасность. В рамках исследований различных механизмов управления политической безопасностью сегодня интенсивно развивается информационное, или - информационно-психологическое, управление.

Авторы, исследующие операции информационно-психологической войны (информационно-политический подход), как военные, так и гражданские, занимают несколько иную позицию: большинство из них считает, что сегодня информационно-психологическая война ведется постоянно, на всех стадиях развития политических конфликтов, а сами политические конфликты носят характер «информационно-политических»². Таким образом, в течении современного политического конфликта нет ярко выраженной поворотной точки, которой была бы фаза ИПВ,- психологическая война сопутствует конфликту всегда. С этой точки зрения, современный конфликт можно урегулировать, защитив государство и общество от агрессивных наступательных технологий информационно-психологической войны, что можно сделать только с помощью таких же технологий оборонительного и превентивного характера.

Представители этнополитического подхода справедливо указывают на то, что «ни один политический курс не может увенчаться успехом, если он идет вразрез с ментальным сознанием этносов, населяющих государство» ${ }^{3}$. Соответственно, урегули-

\footnotetext{
${ }^{2}$ В. Д. Попов, Информациология и информационная политика. М.: Из-во РАГС, 2005.

3 Там же, с. 14.
} 
рование этнополитических конфликтов это обеспечение совместимости вектора политического курса вектору ментальности населения, что можно осуществить только с помощью информационно-психологического воздействия, причем, как на массовое и индивидуальное сознание этносов и этнических групп, так и на подсознательную (ментальную) составляющую человеческой психики, с ее установками и реакциями.

Однако, эффективность существующих сегодня парадигм политического регулирования современных политических, в том числе международных, конфликтов не соответствуют требованиям обеспечении международной безопасности и стабильности:

- множественность политических конфликтов продолжает возрастать, сохраняется тенденция на обострение уже существующих и возникновение новых форм;

- современные этнополитические конфликты все более приобретают вид глобального «столкновения цивилизаций»;

- в очагах международной нестабильности возрастает риск возникновения локальных вооруженных конфликтов, с перспективной втягивания в прямую

\section{Библиография}

1. Доктрина информационной безопасности Российской Федерации // Российская газета. 2000. 28 сент.

2. Основы государственной политики в области обеспечения информационно-психологической безопасности. Проект. М.: Институт психологии РАН, 2000.

3. Угрозы и вызовы в сфере информационной безопасности, Материалы парламентских слушаний в Государственной Думе вооруженную конфронтацию целых регионов;

- международная деятельность по урегулированию политических конфликтов переживает глубокий системный кризис, требующий не только поиска новых подходов и способов воздействия на конфликтные ситуации, но и формирования новых парадигм управления политическими конфликтами.

Bсе это требует выработки новых концепций и представлений о современной роли психологического фактора в разрешении конфликтов, в том числе - на базовом, парадигмальном, уровне.

В условиях формирования глобального информационного общества в современных конфликтах появилась новая фаза - информационно-психологическая война, которая занимает промежуточную ступень между политическим кризисом и фазой вооруженного столкновения, являясь при этом «поворотной точкой» от мирной фазы к военной. В этой фазе технологии информационно-психологического воздействия на политические (в том числе, международные) конфликты становятся одним из решающих факторов и высокоэффективных инструментов в деятельности по их политическому разрешению.

ФС РФ, ГД СФ России, 1996 г.

4. Лебедева М.М. Политическое урегулирование конфликтов: подходы, решения, технологии.- М.: Аспект Пресс., 1999.$271 \mathrm{c.}$

5. Манойло А. В. Проблемы и перспективы исследования информационно-психологических технологий разрешения международных конфликтов. // Право и политика.-2008.— № 3.

6. Kuhn T., The Structure of Scientific Revolution. Chicago, 1970. 
7. Независимая газета, 7 декабря 2007 г.

8. Манойло А.В. Технологии несилового разрешения современных конфликтов. / А.В. Манойло; под ред. проф.

А.И. Петренко.- М.: Горячая линия Телеком, 2008.-392 с.: ил.

9. Манойло А.В. Психологические операции США в Ираке. // Космополис._-2008.№ 1.- C.124-128.

10. Панарин И.Н. Технологии информационной войны. М.:2003, КСП+, 320 с.

11. Панарин И.Н., Информационная война, PR и мировая политика. М.: 2006, Горячая линия-Телеком, $352 \mathrm{c}$.

12. Manoïlo A. V., Gestion de la guerre psychologique dans le cadre de la politique informationnelle de l'Etat.—M.: Politique et société, № 2’ 2004.

13. Manoilo A. V., Methods of Psychological Warfare Research.- V.: Proceedings of The Forth International Scientific and Methodic Conference "IES-2004", 2004, pp. 372-374.

14. Manoilo A. V., Psychological Warfare Management.- V.: Proceedings of The Forth International Scientific and Methodic Conference "IES-2004", 2004, pp. 375-378.

15. Манойло А. В. Пределы регулирующего воздействия информационно-психологических технологий на международные конфликты / А. В. Манойло // Право и политика.—2008.—№ 7.— С.1653-1664.

16. Клименко 3. В. Кризис и распад Югославской Федерации //Дисс... канд. полит.наук.- М., 1999.

17. Манойло А. В. Мирное разрешение конфликтов: национальные концепции, модели, технологии // Власть.- 2008.— № 8.C.79-84.

18. Концепция внешней политики Российской Федерации от 17.12.1997 г., в редакции Указа Президента РФ от 10.01.2000 г. № 24.

19. Мелюхин И. С. Информационное общест- во: истоки, проблемы, тенденции развития. М. 1999.

20. Попов В. Д. Информациология и информационная политика. М.: Изд-во РАГС, 2001, $118 \mathrm{c}$.

21. Попов В. Д. Государственная информационная политика: состояние и проблемы формирования, 2002 г.- М.: Массовые информационные процессы в современной России. Очерки/Отв.ред. А. В. Шевченко. Изд-во РАГС, с.20.

22. Лисичкин В. А., Шелепин Л.А. Третья мировая информационно-психологическая война.- М., 1999.

23. Расторгуев С.П. Информационная война.- М.: Изд-во “Радио и связь”, 1999.

24. Почепцев Г.Г. Психологические войны.Изд-ва: “Рефл-бук”, “Ваклер”, 2000.

25. Прокофьев В.Ф. Тайное оружие информационной войны.- “Синтег”, 1999.

26. Попов В. Д. Информациология и информационная политика.- М., 2001.

27. Манойло А.В. Несиловое регулирование международных конфликтов. Культурно-цивилизационные парадигмы. // Космополис.-2008.- № 2.

28. Шубин А. Россия и мир в 2020 году. Доклад Национального разведывательного совета США «Контуры мирового будущего» М.: Издательство «Европа», 2005.- $224 \mathrm{c}$.

\section{References (transliterated)}

1. Doktrina informatsionnoi bezopasnosti Rossiiskoi Federatsii // Rossiiskaya gazeta. 2000. 28 sent.

2. Osnovy gosudarstvennoi politiki v oblasti obespecheniya informatsionnopsikhologicheskoi bezopasnosti. Proekt. M.: Institut psikhologii RAN, 2000.

3. Ugrozy i vyzovy v sfere informatsionnoi bezopasnosti, Materialy parlamentskikh 
slushanii v Gosudarstvennoi Dume FS RF, GD SF Rossii, $1996 \mathrm{~g}$.

4. Lebedeva M.M. Politicheskoe uregulirovanie konfliktov: podkhody, resheniya, tekhnologii.— M.: Aspekt Press., 1999.— 271 s.

5. Manoilo A. V. Problemy i perspektivy issledovaniya informatsionnopsikhologicheskikh tekhnologii razresheniya mezhdunarodnykh konfliktov. // Pravo i politika.-2008.- № 3.

6. Kuhn T., The Structure of Scientific Revolution. Chicago, 1970.

7. Nezavisimaya gazeta, 7 dekabrya $2007 \mathrm{~g}$.

8. Manoilo A. V. Tekhnologii nesilovogo razresheniya sovremennykh konfliktov. /

A.V. Manoilo; pod red. prof. A.I. Petrenko.— M.: Goryachaya liniya - Telekom, 2008. — 392 s.: il.

9. Manoilo A. V. Psikhologicheskie operatsii SShA v Irake. // Kosmopolis.—2008. № 1.- S.124-128.

10. Panarin I.N. Tekhnologii informatsionnoi voiny. M.:2003, $\mathrm{KSP}+, 320 \mathrm{~s}$.

11. Panarin I. N., Informatsionnaya voina, PR i mirovaya politika. M.: 2006, Goryachaya liniya-Telekom, $352 \mathrm{~s}$.

12. Manoïlo A.V., Gestion de la guerre psychologique dans le cadre de la politique informationnelle de l'Etat.- M.: Politique et société, № 2’ 2004.

13. Manoilo A. V., Methods of Psychological Warfare Research.- V.: Proceedings of The Forth International Scientific and Methodic Conference "IES-2004", 2004, pp. 372-374.

14. Manoilo A.V., Psychological Warfare Management. - V.: Proceedings of The Forth International Scientific and Methodic Conference "IES-2004", 2004, pp. 375-378.

15. Manoilo A.V. Predely reguliruyushchego vozdeistviya informatsionnopsikhologicheskikh tekhnologii na mezhdunarodnye konflikty / A. V. Manoilo // Pravo i politika.—2008.—№ 7.—S.1653-1664.
16. Klimenko Z.V. Krizis i raspad Yugoslavskoi Federatsii //Diss... kand.polit.nauk.- M., 1999.

17. Manoilo A. V. Mirnoe razreshenie konfliktov: natsional'nye kontseptsii, modeli, tekhnologii // Vlast'.— 2008.— № 8.S.79-84.

18. Kontseptsiya vneshnei politiki Rossiiskoi Federatsii ot 17.12.1997 g., v redaktsii Ukaza Prezidenta RF ot 10.01.2000 g. № 24.

19. Melyukhin I. S. Informatsionnoe obshchestvo: istoki, problemy, tendentsii razvitiya. M. 1999.

20. Popov V. D. Informatsiologiya i informatsionnaya politika. M.: Izd-vo RAGS, 2001, $118 \mathrm{~s}$.

21. Popov V.D. Gosudarstvennaya informatsionnaya politika: sostoyanie i problemy formirovaniya, 2002 g.- M.: Massovye informatsionnye protsessy $\mathrm{v}$ sovremennoi Rossii. Ocherki/Otv.red. A. V. Shevchenko. Izd-vo RAGS, s.20.

22. Lisichkin V. A., Shelepin L. A. Tret'ya mirovaya informatsionnopsikhologicheskaya voina.- M., 1999.

23. Rastorguev S. P. Informatsionnaya voina.M.: Izd-vo "Radio i svyaz", 1999.

24. Pocheptsev G. G. Psikhologicheskie voiny-— Izd-va: "Refl-buk", "Vakler", 2000

25. Prokof'ev V.F. Tainoe oruzhie informatsionnoi voiny._- "Sinteg", 1999.

26. Popov V. D. Informatsiologiya i informatsionnaya politika.- M., 2001.

27. Manoilo A. V. Nesilovoe regulirovanie mezhdunarodnykh konfliktov.

Kul'turno-tsivilizatsionnye paradigmy. // Kosmopolis.—2008.—№ 2 .

28. Shubin A. Rossiya i mir v 2020 godu. Doklad Natsional'nogo razvedyvatel'nogo soveta SShA «Kontury mirovogo budushchego» M.: Izdatel'stvo «Evropa», 2005. - $224 \mathrm{~s}$. 